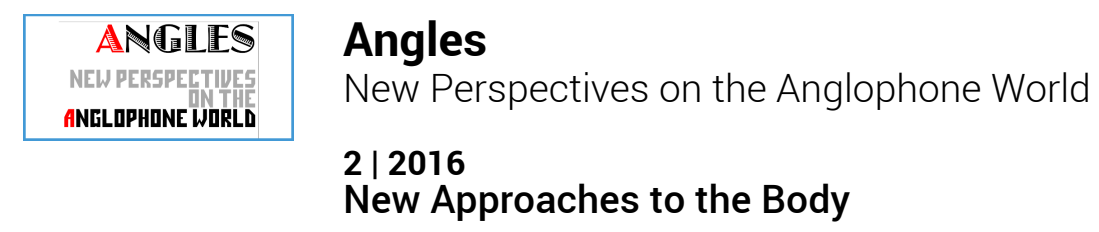

\title{
An A to $\mathrm{Z}$ of Diasporic Life
}

\section{Françoise Král}

\section{(2) OpenEdition}

\section{Journals}

Electronic version

URL: https://journals.openedition.org/angles/1967

DOI: 10.4000/angles. 1967

ISSN: 2274-2042

\section{Publisher}

Société des Anglicistes de l'Enseignement Supérieur

\section{Electronic reference}

Françoise Král, "An A to Z of Diasporic Life", Angles [Online], 2 | 2016, Online since 01 April 2016 connection on 06 June 2022. URL: http://journals.openedition.org/angles/1967 ; DOl: https://doi.org/ 10.4000/angles. 1967

This text was automatically generated on 6 June 2022.

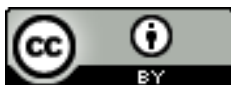

Angles est mise à disposition selon les termes de la Licence Creative Commons Attribution 4.0 International. 


\title{
An A to Z of Diasporic Life
}

\author{
Françoise Král
}

\section{A}

\section{$A$ is for amnesia}

1 Emotional erasure of a place left behind in haste. A few belongings packed in a bag, a few mismatched items of clothing thrown together in a suitcase and some photos of a past one aches to part with. Sometimes a gramophone playing a few notes from a bygone era of pre-exilic bliss, drifting up to unresponsive ears and cold indifference, a jarring Masala of sounds and tones.

2 In the rearview mirror, the last glimpse of a motherland the exile fears he or she will forget while the economic migrant secretly longs to return; the coastline receding towards the horizon, its smells becoming more distant, its inhabitants like specks of dust on a line. A 'line of flight', a long list of incipits leaving the Distant shore behind; a Final Passage, a Voyage in the Dark...

3 Amnesia as collective amnesia and the need to nurse the dissolving bond with other diasporians once the umbilical cord with the homeland has been severed.

4 Structural amnesia, imposed by colonization, its crushing political structures forced upon the people, its language yoked to a reality it fails to fully capture and render, its history annihilating that of the country it was made to take over and whose children's heads are emptied and then filled with the long lists of the glorious deeds of their Gaulish ancestors.

5 And in the end, the long-term amnesia of a country crushed by colonial history: total erasure, a blank slate, a point of no return. 


\section{$B$ is for body}

6 Bodies deprived of their nourishment, forced to get used to foreign tastes and flavours; bodies craving the food of the nurturing land.

7 Culinary memoirs, weaving generations together over the years, a continuum of smells and textures, an exuberant garishness of subtle flavours, passed on from generation to generation, from mothers to daughters, bringing the home alive.

8 Mnemonic shrapnels encysting the memory of the diasporian, triggering bouts of melancholia or desperate attempts to recreate a flavour, a texture long lost and frozen in the atemporal bliss of childhood memories. Namesakes and ersatz of Indian cakes translated into the culinary grammar of spices made available on a global scale.

9 The body of the group at last as a ghostly presence and performative figure in a postdeparture life; a need to connect, to bond, to cling together, through language and habits, through a commonality of experience.

10 Starving bodies, the bodies of those who drown, of those who never make it to the Distant Shore and whom the Distant Shore lets down.

11 Bodies of oblivion, the drowned, the diseased, the forgotten precarious lives lost in migration, hopelessly scattered and never to return, lives hardly mourned and never remembered, bodies adrift without a gravestone to remember them by. Liquified bodies of grief peopling our oceans to global indifference or intermittent focus, eyed suspiciously.

12 B is for 'bodyscape', visual landscapes of faces and features, made more familiar over the years, through photos and films, free-floating images making foreignness less foreign. And yet, laid out on the page, overexposed in lights too bright not to blink, the 'other' gazes back, equally opaque if not more so, despite repeated exposure, shrouded in multi-layered coats of discursive nonsense - brightness leading to more obscurity.

\section{B is for Sonia Boyce, British artist of Guyanese origin (1962- )}

13 Her vocal paintings denouncing missionary positions of power and Western scopophilia, the unlimited peeping at the disempowered, the noxious collusion of cognition and exploitation, climaxing in uninvited intrusions. Peep, an exhibition, a statement, forcing us to embrace and assume the role of peeping toms, up on our toes or bending forward to sneak a peek, as if through a keyhole, at the artefacts shrouded in paper. The West, framed and forced into the picture, forced to go through the looking-glass and stare back at its unhealthy curiosity; ugly monsters of perversion in disguise. 


\section{C is for cut,}

\section{$\mathrm{C}$ is for caesura,}

14 C sections of emotional pain as the migrant is uprooted from the nurturing land. The unbridgeable gap widening by the hour, the impossible return to a homeland whose receding line of flight progressively goes out of focus, while the migrant continues to follow his/her course away from it, hovering away in mock oblivion and imperfect remembrance, shrouded in misty recollections of Imaginary Homelands.

Still, the separation is real, the return impossible and the past on its way to being forgotten.

$\mathrm{C}$ is for cut, $\mathrm{C}$ is for caesura - the fantasized host country versus the reality, the myth - the promised land of unkept promises, of hopes deceived, a land of loneliness, a cold embrace for a heartless welcome, a sea of blind faces blinding him in return, leaving him staggering, his qualities unnoticed, his life unlived, his story untold.

D

\section{$D$ is for diaspora,}

17 Diaspora, dia speirein, a scattering of fragments left to disseminate, yet longing to reunite into an aggregate, a whole, a body of others, resedimenting the past in a foreign land, fossilized fragments seeking refossilization in foreign territory. Historical diasporas which continue to haunt the citizen of the $21^{\text {st }}$ century, the Jews, the Armenians, but arguably other diasporas whose sense of group identity and national filiation has resisted the passing of time and the blow of distance and estrangement, to continue to look back and see this façade of a home they long to return to.

\section{D is for Ernest Dyche (1887-1973) Birmingham-based photographer,}

his portraits a photographic chronicle of the changing face of Britain; new faces, new figures, West Indians sporting their uniforms as nurses or bus drivers, South Asians posing confidently in their Sunday best. Racial others no longer relegated to the margins of popular iconography but coming centre stage, confident, empowered, a pictorial revolution by means of commercial portraiture, leaving behind the feminized figures unmanned by orientalist painters, frozen in an atemporal stasis - horses standing still, movement coming to a halt, a surreal space from which time has been banned. 


\section{$E$ is for exile}

19 A more radical form of diaspora, wrenching one from the beloved bosom of the homeland often for quite some time, possibly forever. The fear of leaving for good and never to return, the need to forget and fight off the urge to remember and grieve. Exile, exiled, hopefully a temporary stage, a station of the cross, the better to return.

\section{$E$ is for exhibitions}

20 - forced displays of commodified bodies belonging to individuals whose consent has not been sought; Hottentot Venuses - their bodies, coveted in the name of science and cognition, eyed and handled without any precaution, dissected, desecrated, disposed of.

\section{$E$ is for eclipse,}

21 The eclipse of the body in $20^{\text {th }}$ century art, a strange irony of art history. A body aching to return and bear witness to the horrors it has been through. Bodies of 'others', bodies of evidence, evidently absent. Eclipsed by new fads, a swing of the pendulum, a strange coincidence, the black body steps in, exit the white body, exit the body in the great invisibilizing shift to abstract art - Mirzoeff's blinding truth.

F

\section{$F$ is for fences,}

Boundary lines of shame barely containing floods of people - ribbons of human silhouettes, expanding and shrinking, and then stretching to breaking point, snaking in and out of a pitch black tunnel in the hope of a luminous exit.

\section{$F$ is for fractus,}

the unredeemable break, a permanent cut - before and after, home and away, and then the polarities are swapped. Hovering back and forth for years, the home becomes foreign and the foreign land is tamed, in check, under control.

\section{$F$ is for fractal,}

24 a large-scale disaster of gaping inequities getting worse by the hour, unfair, unfairer, as the rich get richer and the poor poorer. No longer going West, they all have to go South, where the rents are low and the purchasing power high, purchasing power, poor chasing power, deterritorialized puppets entangled in rhizomatic roots, pawns on the global chessboard wiped off the board by the Kings, Queens and Bishops of global capitalism. 


\section{$\mathrm{G}$ is for Ghost}

Ghostly presences haunting our memory, ghosts lingering on well past their move out date. Invisible presences showing us the way back into the past, a move forward a step backward.

Gothic forms of textual subversion.

Gory details relegated to the footnotes of official history, Ghosting the archives, lurking in the Dark of Heartness.

\section{$\mathrm{G}$ is for geographies, imaginary geographies,}

a blurred global landscape of shifting lines firmly cutting across the land. Virtual territories superimposed on existing nations, mediascapes, technoscapes, financescapes: the new realities of a market-colonized world. Pockets of wealth and pockets of poverty side by side, a distended archipelago where the various units have ceased to interface. Islands drifting apart, a fractal geography of pain, a fractal geography of loss. And everywhere huddled masses lost in the chaos-world, marching on, stomping a march of global dissonance.

\section{$\mathrm{G}$ is for Edouard Glissant (1928-2011)}

and his polyphonous mapping of a chaos-world; the jarring ensemble chartered in his Poétique de la Relation; visionary statements seen through a Caribbean lens, a rich complexity as entry point into the Tout-Monde, a call for a polyglossic world of thriving heteroglossia, read and told in all the languages of the World.

\section{$\mathrm{H}$}

\section{$\mathrm{H}$ is for home,}

31 A transient shape caught in the rearview mirror. S/he tries not to look back, turns a blind eye on the face of grief, concentrating hard on what looms ahead, a façade of a new home, like a mirage in the desert, hazy and out of reach. A ghostly shape calling us, compelling us to go nearer.

Icarus's myth, played out over and over again. Yet s/he marches on, no pain, no gain.

Home, the prospective façade, the light ahead without which the progress would come to an end, the necessary milestone which makes collective dreams seem possible.

\section{$\mathrm{H}$ is for home,}

real homes, cosy homes, not makeshift camps with tin roof huts and no lavatories. 


\section{$\mathrm{H}$ is for Home,}

Mona Hatoum's installation, featuring a set of metallic kitchen utensils laid out on a table, encased in an open space fenced in by electric wires making sizzling noises; home turned into an open space, up for grabs and unprotective, yet enclosed in its inexistent cosiness, its coldness, its sense of danger and precariousness. Home as cold rather than cosy, sharp rather than soft, a space, not a place, where there is no respite : buzzing sounds keeping you awake, artificial humming where there is no homing in; the open space of exposure, a shocking absence of privacy, bodies exposed, transient, unrooted, unmoored, cordoned off but unable to settle, take root or spread their wings and escape the constricting borderlines of horror. Inspired by an exilic trajectory of the twice displaced, a country not fully bidden farewell to and yet left behind for good, a life rerooted in a safe haven, but an ethical need to expose the ongoing horror of displacement and exile.

\section{I}

\section{I is for in-between}

The in-betweenness of the migrant, eternally moored to the homeland whilst casting new roots in a new land.

In-between languages, his mind inhabited by foreign idioms and hard-wearing turns of phrase, linguistic weeds constantly reappearing, rhizomatic, rippling around an epicentre of pain. A lingering presence casting a disturbing shadow on a reborn self.

\section{I is for islands,}

disseminated fragments, autonomous entities, separate units in a world gone global, a world of un/commonwealth, an ugly archipelago of ill-matched fragments, a messy quilt. Jarring atoms of an irredeemable future, drifting apart, ever-apart.

\section{$J$}

\section{$\mathrm{J}$ is for Gish Jen, Chinese American novelist;}

her Mona seeking a Promised Land. Mona and other typical Americans finding their way through the changing geography of the city, constantly on the move, catchmenthunting, social climbing. Models of integration fitting into the mold of the model minority, melting into the melting pot, a vortex of different ethnicities, all absorbed in their own time into the core of the nation, a morphing core, a changing sense of nationhood. 


\section{$\mathrm{K}$}

\section{$\mathrm{K}$ is for Kempadoo, Roshini Kempadoo, Black British artist casting new light on colonial oppression}

40 - digitalized scenes of Sweetness and Light (1996-7), staging the internalized subservience of the doubly crushed - women, ancestors, mothers and daughters, depositories of a legacy of convenient commodification, objects of desire, objects, objectified, curious specimen eyed with unconcealed greed; rotating figures on display, aligned, up for grabs.

$\mathrm{L}$

\section{$L$ is for loneliness,}

41 the solitude of unmoored lives floating adrift, the Lonely Londoners and their Inheritance of Loss, doubly alienated by unwelcoming hosts and scornful fellow countrymen.

L is for loneliness - liberating as well - room for reinvention with limited luggage instead of trunks full of trinkets cramming a home hardly settled.

43 Light luggage - a gunny sack - or no luggage at all, the better to reinvent oneself freely melting into the liquid modernity of our contemporary lives.

Light-footed female footprints tiptoeing their way into the world outside, into Brick Lane and further afield, the Nazneens, Ashimas and Jasmines of this world.

M

\section{$M$ is for migrants - not emigrants, not immigrants - but migrants,}

doomed to migrancy, ever to migrate - a transitory stage turned into a status - a no man's land for life, bounced back, kicked out, short-term acceptance with a proviso, roots with no room to reroot, lives hanging by a thread, dangly puppets dropped in the ocean and drowning.

Media coverage, intense but intermittent, fleeting, flimsy silhouettes, they frazzle out of focus dissolving into the one word: Migrant.

Migrant, an awkward present participle creeping into common language - citizens and fellow human beings, wake up to the horror - the horror the horror!

\section{$M$ is for museums and their archaeology of the past,}

the compulsive archiving and displaying without self-examination. The relentless race for more artefacts leaving African villagers aghast and traumatized, Dakar expeditions and their cultural ethnocides. 


\section{$\mathrm{N}$ is for Notes,}

compulsive note-taking of the first explorers, keen to note and order, telegraphic style for a fact-based study parading as science, parading as knowledge.

\section{$\mathrm{N}$ is for Mira Nair and her insights into Indian life and its diasporas,}

Masalas and other hybrids, cultural mixes rerooted and always on the go - Indians in Kenya, kicked out and doubly diasporized, twice subalterns.

0

\section{0 is for oblivion,}

51 tentative, imperfect, yet obligatory, a wilful quest to mute the past and prevent it from choking the shrill cries of joy of the rerooted, rerouted subject.

$\mathbf{P}$

\section{$P$ is for Palimpsest}

In lieu of a tabula rasa - under the surface, a subtext of pain written in bright indelible ink - scratching the surface, laying it bare, the pain lies there, unerased, irreducible.

Linguistic palimpsests inscribed upon the body, words scarring an immaculate skin, Measures of Distance laid bare for all to see, the body exposed in all its honesty.

\section{$P$ is for partition,}

an ugly scar for an unhealed wound - a legacy of pain scarring the land, marring the surface, cutting into the flesh of the country - a symbolic dismemberment, two halves of a name cut in two, useless corridors leading up to a wall, rooms without a door to enter or exit the shadow lines of pain; for who does the bell toll? For Midnight's children awaiting in the womb.

Partition trains taking their bloodied cargo of sacrificial victims home, a line of impossible flight, a line of shame tearing families apart, and among the victims, women, wives or sisters, mothers or daughters parted by partition.

\section{P is for Piper - Keith Piper - Black British artist and figurehead of the BLK movement,}

Piper's Still for the Fictions of Science, a subtle visual palimpsest, a side view of a man, a black man, "negroid type", freely framed; measuring devices, a silent hymn to poor Saartje. And definitions, craniology; a name one can barely make out and whose boundaries are not clear, the bare bones of human ignorance parading as science. A 
line, a hazy line, science and pseudo-sciences, craniology, phrenology, a quantum of nonsense followed by an infinity of pain. Science beware thy destructive hubris.

\section{P is for Phillips - Caryl Phillips}

57 - a Kittitian-originated journey for a transatlantic œuvre, an inveterate diasporian relentlessly mapping the complex cartography of his Atlantic Home, penning plots about forced displacement, charting invisible trajectories of pain - the uncharted lives of the great invisible - spectral presences of Lost Children lost in migration. Phillipsian trajectories of pain leaving emotional footprints, haunting voices caught in an echo chamber of textual entanglements cazually weaving their way into criss-crossing yarns while his reader learns to tune in to the Atlantic Sound.

Q

\section{$Q$ is for quest}

58 - the alpha and omega of the diasporic tale, a quest for a better life, seeking more, seeking better, hoping to make it big in the land of failed promises. A quest turned into a request, an unheard one lost on deaf ears.

$\mathbf{R}$

\section{$R$ is for Larry Rivers}

59 - I Like Olympia in Black face; not a negro teamster nor a corked figure made to entertain the white spectator, but a vocal response to Manet's Olympia and its black figure fading into the dark background. The black female coming centre stage, a daring nude venturing into taboo territory; a respectful take for a crafty artwork cunningly playing with the codes of 3D artwork, the curvaceous body lying flat, the erotic power neutralized, and all that there is left are shades of blackness, shades of whiteness, a healthy hybrid, not a decadent monster of our fearful imaginations. Ironic inversions.

\section{R is for Rose, Tracy Rose, South African artist (1974-)}

60 Rose's bodies of hope in a newly reconciled society, luscious entanglements of love, Rodin revisited, A Kiss, Just a Kiss. Apartheid brought to an abrupt end in an embrace.

\section{$R$ is for return, the impossible return, yet always on the horizon}

61 Impossible: How to go back and admit defeat, intense weariness, the pain of unbelonging, the agony of repeated pretense. Return? Impossible, for it would mean admitting to flaws at the heart of the promised land, a fake myth, its streets not paved with gold. Return? Impossible, home is no longer home, they have moved on while part of him has stayed the same, a fossilized fragment seeking refossilization. 


\section{$R$ is for Donald Rodney, Black British artist (1961-1998)}

In the House of My Father (1997) a disturbing sculpture made with the artist's own flesh, a strange exhibit, tiny, delicate, disturbing, held in the palm or his hand, the skin, strangely translucent, black yet not really black. A question of light, a question of exposure, blackness relativized. An ode to the body, a work exposing art's tentative attempt to transcend death. An unreasonable promise unkept.

S

\section{$S$ is for surprise}

\section{$S$ is for shock}

Stepping out of the boat on a frigid morning, finding one's way out of the train station on a foggy day - Shocking truth behind the myth: no promised land in sight but dingy streets and bleak façades, streets to the left, streets to the right, streets and alleys, none of them paved with gold. Hopping on a double-decker with a vague goal in mind, heading for the job centre.

64 Tales of the two Cities, the real and the imaginary, the promised land flanked by its pathetic Dopplegänger.

\section{$S$ is for Selvon}

65 - Sam Selvon's insightful chronicle of the impossible move: Moses Ascending, Moses Migrating. Moses unsettled, seeking a land of milk and honey, seeking solace back in a homeland that's no longer a home.

66 Sea crossings made by the first explorers as a prerequisite for later expansion, appropriation, colonization. Sea crossings, slaves huddled in overcrowded slave ships, travelling in the dark, malnourished, cold and sick, sometimes ill, dying, dead, thrown overboard, and forgotten until the big awakening, too late, too mute, too focused and not performative enough to avoid the new deaths at sea.

\section{$\mathrm{S}$ is for silence,}

67 silenced testimonies and untold stories, silence of the polyglot whose voice is trapped in the sonorities of a linguistic straitjacket, uttering sounds thought of as gibberish, seeking the right shade of meaning, speaking the same language in a foreign tongue, struggling to translate jokes or simply to express himself, his voice lost in translation. His untranslated self has stayed home while an ersatz has made the journey.

\section{$\mathrm{T}$}

\section{T is for Turner's Slavers throwing overboard the Dead and Dying,}

slaves thrown overboard to secure insurance money, dying an unnatural death, a bloodied cargo, an unethical gamble, slaves drowning and sinking to the bottom of the 
sea while the ship moves on, making hasty progress towards its fatal end, sky clouding into dark layers of ominous clouds announcing judgment day. The two lives of the painting, a mild welcome on British soil, a sea of criticism in the land of freedom, a feast of bad faith as all eyes are focused on the floating manacles awkwardly defying gravity. Lives vanishing without so much as a place of Memory to remember them by, greedy fish ready to eat the remains. A good dose of poetic license forcing us face to face with a conveniently invisible outcome had gravity done its job. The manacles would have conveniently drowned and the corpses would have been invisible instead of floating up to remembrance. And they went on to be remembered, by poets, from Marlene Nourbese Philip's Zhong! to David Dabydeen's sequel to Turner's painting.

Slaves, invisible shapes of D'Aguiar's novel Feeding the Ghosts.

\section{U}

\section{$\mathrm{U}$ is for unlearning}

- unlearning a life, a language and a place, a former self left behind.

\section{$\mathrm{U}$ is for unmooring,}

letting go of one's bearings and beliefs, stepping out in the open and venturing onto shaky ground.

Utopia, impossible, incorrect, a gross caricature that no one dares to denounce, so they march on, seeking the cold embrace of its Distant Shore, a dystopic truth of numbing hideousness.

\section{V}

\section{$V$ is for vortex}




\section{W}

\section{$W$ is for wheelchair}

81 as in Mona Hatoum's compelling artwork featuring a wheelchair whose handles are two blades; a strange mix of adverse emotions, sympathy empathy and fear. An empty chair as an ode to an absent body, dead, dying, or gone never to return, a symbol of frailty turned into a weapon, a strange interplay of adverse emotions. A fine line, a cutting line, bringing the viewer's face to face with the reality of traumatic diasporas, the unchosen move to save one's life.

\section{$\mathrm{W}$ is for weavers,}

Hatoum's installation at the Béguinage Ste Elizabeth, Kortrijk; a large room, abandoned, deserted but not empty; balls of hair scattered on the floor, an ode to a long gone community of weavers, a remote presence, an invisible footprint leading to a forgotten past - a short sense of intimacy.

\section{W is for Wilson, Fred Wilson (1954- )}

His provocative rewriting of American history in the form of museum installations, or rather in the form of insidious juxtapositions in official collections. Refined crockery marred by manacles, a strange coming together of brutality and refinement, a metaphor for history, American slavery, a success story of capitalized wealth based on triangular oppression.

\section{W is for Williams - Bert Williams - black American entertainer at the turn of the $20^{\text {th }}$ century.}

Famous and rich, rich but lost, famous and lost; corking his face to please white audiences, giving them what they wanted to see until they wanted to see him no more.

\section{$X$}

\section{$\mathrm{X}$ is for xenophobia as the point of departure and the finishing line,}

a long-drawn journey of stormy mishaps across oceans for a disappointing finding... looping the loop of human exclusion.

\section{Y}

\section{$\mathrm{Y}$ is for yonder, the ever-moving line of a long journey;}

receding further and further afield like all the other promises immigration had in store for him. Wealth......... yonder......... fame......... yonder........... success............... yonder. better life .just about. 


\section{$\mathrm{Z}$ is for Zhong - notorious slaveship}

87 - floating grave of the 132 slaves thrown overboard by slavers. Rescuing cargo money from probable death by epidemics, pushing them overboard to certain insurancecovered hazard - DEATH - death at sea, death by drowning. Lives that do not count, lives that no one cares about, lives freely disposed of, haunting us, from Turners' slaves ship to literary tributes, a polyphony of humane voices responding to the cold orders uttered by heartless slavers.

\section{BIBLIOGRAPHY}

Ali, Monica. Brick Lane. New York: Scribner, 2004.

Bauman, Zygmunt. Life in Fragments. Essays in Postmodern Morality. Oxford: Blackwell, 1995.

Butler, Judith. Precarious Life: The Powers of Mourning and Violence. London/New York: Verso, 2004.

Ghosh, Amitav. The Shadow Lines. London: Bloomsbury Publishing, 1988.

Gilman, Sander L. 'Black Bodies, White Bodies: Toward an Iconography of Female Sexuality in Late Nineteenth-Century Art, Medicine, and Literature.” Critical Inquiry 12.1 (Autumn 1985): 204-242. DOI: $10.1086 / 448327$

Glissant, Édouard. Poétique de la Relation. Paris: Gallimard, 1990.

Glissant, Édouard. Traité du Tout-Monde. Paris: Gallimard, 1997.

Jen, Gish. Mona in the Promised Land. London: Granta Books, 1997.

Král, Françoise. Critical Identities in Contemporary Anglophone Diasporic Literature. New York/ Basingstoke: Palgrave Macmillan, 2009.

Král, Françoise. Social Invisibility and Diasporas in Anglophone Literature and Culture: The Fractal Gaze. New York/ Basingstoke: Palgrave Macmillan, 2014.

Lahiri, Jhumpa. The Namesake. New York: Houghton/Mifflin, 2003.

Memmi, Albert. Portrait du Colonisé, Portrait du Colonisateur. Paris: Corréa, 1957.

Mirzoeff, Nicholas. Bodyscape. Art, Modernity and the Ideal Figure. New York: Routledge, 1995.

Mukherjee, Bharati. Jasmine. New York: Grove Press, 1989.

Phillips, Caryl. The Final Passage. London: Faber \& Faber, 1985.

Phillips, Caryl. A Distant Shore. London: Secker and Warburg. 2003.

Nourbese Philip, Marlene. Zong! Middletown: Wesleyan UP, 2008.

Rhys, Jean. Voyage in the Dark. London: Penguin 2000 [1934]. 
Roy, Arundhati. The God of Small Things. London: Flamingo, 1997.

Rushdie, Salman. Midnight's Children. London: Jonathan Cape, 1981.

Rushdie, Salman. Imaginary Homelands: Essays and Criticism, 1981-1991. London: Granta Books, 1991.

Said, Edward. Orientalism: Western Conceptions of the Orient. London: Penguin Books [1978] 1995.

Marangoly George, Rosemary. The Politics of Home.: Postcolonial Relocations and Twentieth-Century

Fiction. Berkeley: U. of California P., 1999 [1996].

Selvon, Sam. The Lonely Londoners. London: Penguin, [1956] 2006.

Selvon, Sam. Moses Ascending. London Heinemann, [1975] 1984.

Selvon, Sam. Moses Migrating. Boulder: Lynne Rienner, 2009 [1983].

Vassanji, M.G. The Gunny Sack. Toronto: Anchor: 2005 [1989].

Walcott Derek. 'The Sea is History'. Collected Poems, 1948-1984. New York: Farrar, Straus and Giroux. 1986.

\section{List of art works}

Boyce Sonia. Missionary Position II, 1985. Watercolour, pastel and crayon on paper. $1238 \times 1830 \mathrm{~mm}$ $\left(48 \frac{3}{4} \times 72\right)$

Peep. Exhibition, Brighton Museum's Collection of non-Western art and ethnography, 1995.

Kapoor Anish, Descension. Installation, whirlpool of black water. 2014.

Kempadoo, Roshini. Sweetness and Light. 1996-7.

Hatoum, Mona. Home. 1999. Installation. Wooden table, steel, kitchen utensils, electric wire, 3 light bulbs, software and audio.

Hatoum, Mona. Measure of Distance. 1988. Colour video, 15 min.

Lewis, Dave. 'Untitled', Haddon Photographic Collection, Cambridge University Museum of Anthropology and Ethnography, 1985.

Lewis, Dave. https://www.vidaimage.co.uk/

Lewis, Dave. http://www.focaalblog.com/2015/08/03/dave-lewis-field-work/

Piper Keith. Still from the Fictions of Science, 1996.

Piper Keith. http://www.keithpiper.info/

Rivers, Larry. I Like Olympia in Black Face. 1970. Oil on wood and plexiglas, 182x194x100cm.

Rodney, Donald. In the House of my Father. 1997.

Tracey Rose. The Kiss, 2001.

Turner, William J.M. Slavers Throwing overboard the Dead and the Dying - Typhon coming on. 35 $3 / 4 \times 48 \frac{11}{4} .1840$. Oil on canvas.

\section{Films}

Nair, Mira. Mississippi Masala. SCS Films, 1992. US 118 min. 


\section{ABSTRACTS}

'Diaspora' often rhymes with nostalgia for reasons linked to the very nature of diasporic living, from the original moment of 'unmooring' from the homeland, to the process of rerooting of diasporic populations in the host country. The shaping of the collective memory of a diaspora, which marks the specificity of diasporas as opposed to other forms of migrations and their more individual trajectories, takes various forms: the forced erasure of history in formerly colonized countries (Memmi) often leaves an indelible mark which the trauma of loss and the sometimes dramatic contexts of diasporic unmooring reinforce. Memory builds up in a rhizomatic way, randomly weaving together fragments of different contexts, creating a storebank of jarring polarities. The following text seeks to evidence the constitutive iteration of the diasporic psyche from the initial moment of uprooting and displacement which signals the start of diasporic living. It revolves around the forming of a collective memory, passed on and transmitted to younger generations, and which holds the members of the diaspora together. The form of the A to $\mathrm{Z}$ imposes strict formal constraints, which the free-floating associations seek to challenge. The following $A B C$ is by no means an exhaustive presentation of diasporic experience as a whole how could it be - but a personal take on contemporary diasporic writers and artists mainly from the West Indies and South Asia through references and allusions to their works.

L'expérience diasporique est souvent associée à la nostalgie tant la séparation, la perte et le désarrimage sont au cœur de la trajectoire diasporique, au terme de laquelle le sujet replante ses racines dans une patrie d'accueil. La constitution d'une mémoire collective est essentielle car constitutive de la diaspora en tant qu'entité. C'est notamment cette mémoire collective qui distingue l'expérience diasporique d'autres types de migrations aux trajectoires plus individuelles. Cette mémoire collective peut prendre plusieurs formes et aller de l'amnésie forcée, qui est souvent le lot des populations issues des pays anciennement colonisés (Memmi), à une amnésie liée à la perte et au trauma et qui continue de marquer les membres d'une diaspora. Cette mémoire collective se forme tel un rhizome poussant au gré des entrelacs arbitraires et s'agrège à partir de fragments issus de différents contextes qui se côtoient en une cacophonie stridente. Elle perdure au gré de transmissions successives, de génération en génération. Le texte qui suit cherche à mettre en évidence l'itération caractéristique de la psyché diasporée, depuis le moment du 'désarrimage', qui marque le début de l'expérience diasporique. La forme de l'abécédaire pose un certain nombre de contraintes formelles que les associations libres tentent de repousser. Ce texte ne prétend pas à l'exhaustivité - comment d'ailleurs le pourrait-il - mais se veut être un hommage à des écrivains ou artistes contemporains originaires de l'Inde ou de la Caraïbe.

\section{INDEX}

Mots-clés: Boyce Sonia, Glissant Édouard, Hatoum Mona, Lewis Dave, Nair Mira, Phillips Caryl, Piper Keith, Rhys Jean, Rushdie Salman, Selvon Sam, Walcott Derek

Keywords: Boyce Sonia, Glissant Édouard, Hatoum Mona, Lewis Dave, Nair Mira, Phillips Caryl, Piper Keith, Rhys Jean, Rushdie Salman, Selvon Sam, Walcott Derek 


\section{AUTHOR}

\section{FRANÇOISE KRÁL}

Françoise Král is Professor of English and Postcolonial studies at the University of Caen

Normandie (France). Her publications include two monographs in the field of diasporic studies, Critical Identities in Contemporary Anglophone Diasporic Literature (Palgrave, 2009) and Social Invisibility in Anglophone Diasporic Literature and Culture: The Fractal Gaze (Palgrave, 2014). She has co-edited two books: Re-presenting Otherness: Mapping the Colonial 'Self /Mapping the Indigenous 'Other' in the Literatures of Australia and New Zealand (2004) and Architecture and Philosophy: New Perspectives on the Work of Arakawa and Gins (co-edited with Jean-Jacques Lecercle, Rodopi, 2011) and guest-edited an issue of Commonwealth, Essays and Studies, Crossings (37.1 autumn 2014). She had published many articles in the field of postcolonial literature and diasporic studies and is coorganizer of the 'Diasporic Trajectories' seminar series (IASH, University of Edinburgh 2015-2016) which focuses on diasporic studies viewed through the dual lens of Anglophone and francophone diasporas. Contact: fmkral [at] gmail.com 